\title{
IDENTIFICATION OF SEX IN ZAMIA INERMIS USING ISSR MARKERS
}

\author{
$\underline{\text { Lourdes Georgina IGLESIAS-ANDREU }}^{1 *}$, Enrique FAVIÁN-VEGA ${ }^{1}$
}

${ }^{1}$ Instituto de Biotecnología y Ecología Aplicada (INBIOTECA), Universidad Veracruzana, Avenida de las Culturas Veracruzanas 101, Colonia Emiliano Zapata, C.P. 91090, Xalapa, Veracruz - Mexico.

* Corresponding author. E-mail: liglesias@uv.mx

\begin{abstract}
Zamia inermis is a dioecious cycad endemic to the State of Veracruz that is on the risk extinction. Sexspecific markers are important in understanding the mechanism of sex determination. However, since little is known about the mechanism of sex determination in Z. inermis, we proposed looking for Inter-simple Sequence Repeats (ISSR) markers that could be linked to sexual expression in this species. Using DNA bulk samples of male and female genotypes and 6 ISSR primers, a female marker ( $867 \mathrm{bp})$ was identified with primer ISSR-18, which was present in $66 \%$ of the DNA mixtures of the female genotypes analyzed. The results of the Principal Coordinate Analysis performed revealed a tendency for clustering of genotypes of the same sex.
\end{abstract}

Keywords: conservation, cycad, dioecious, molecular markers, sex.

\section{Introduction}

Cycads are a type of gymnosperm that can be found in tropical and subtropical areas of the world. There are 54 species of cycads in Mexico, divided into three genera (Ceratozamia Brongn., 26 species, Zamia L., 15 species and Dioon Lindl., 13 species). MARTíNEZDOMÍNGUEZ \& al. (2018) found that 89 percent of them are endemic and provide $17 \%$ of the diversity.

Zamia inermis Vovides, J. D. Rees \& Vázq. Torres (Zamiaceae, Cycadales), is an endemic species of Veracruz, Mexico, which is stated as a critically endangered species on the International Union for Conservation of Nature's Red List (IUCN, 2011) and as an endangered species on SEMARNAT's NOM-059-SEMARNAT-2010 [SEMARNAT, 2010]. This is mainly due to the absence of their natural pollinator to low recruitment rates, illegal trade, and land use change [OCTAVIO-AGUILAR \& al. 2017; IGLESIAS-ANDREU \& al. 2017]. Like all cycad species, Zamia inermis is dioecious and it is difficult to determine the sex of seedlings during the early stages of development; additionally, reproductive events are rare, with low and sporadic seed production, from which only a small proportion of seedlings are obtained [OCTAVIO-AGUILAR \& al. 2017]. The morphological evaluation of cycad reproductive structures has been used to determine sex [SÁNCHEZ-TINOCO \& al. 1990; SÁNCHEZTINOCO \& al. 1993; BALDO-ROMERO \& al. 2013]. Other molecular markers, such as Random Amplified Polymorphic DNA (RAPD marker) [WILLIAMS \& al. 1990] and Amplified Fragment Length Polymorphism (AFLP marker) [VOS \& al. 1995], have lately gained popularity.

Although some molecular markers have been successfully employed for sex identification in cycad species such as Encephalartos natalensis R. A. Dyer \& Verdoorn. [PRAKASH \& VAN STADEN, 2006], and Ceratozamia mexicana Brongn. [IGLESIAS- 
ANDREU \& al. 2010], it should be highlighted that markers based on Simple Sequence Repeats (ISSR) [ZIETKIEWICZ \& al. 1994] have been highly efficient for distinguishing the sexes of some cycad species, like Cycas circinalis L. [GANGOPADHYAY \& al. 2007] and Cycas tanqingii D. Y. Wang [JING \& al. 2007], and Ceratozamia mexicana Brongn. [SÁNCHEZCOELLO \& al. 2018] due to their simplicity, abundance, reproducibility, low cost, and speed of analysis. However, no information about its use for this purpose has been found in Z. inermis to date. To contribute to the identification of sex in this species, we propose to develop a genetic sex marker that allows us to gender as well as sex ratio determination at any stage in the life cycle and, eventually, the understanding of sex ratio dynamics in this unique natural population.

\section{Material and methods}

Study site and plant material. The only natural population of Zamia inermis is observed in the Sierra de Manuel Diaz, close to the town of Mozomboa (municipality of Actopan), in the central part of Mexico's Veracruz State [VOVIDES, 1983], between 19³2'54.90" north latitude and $96^{\circ} 27^{\prime} 29.80^{\prime \prime}$ west longitude [VOVIDES, 1983]. This population, which is distributed across about $2.5 \mathrm{~km}^{2}$ of seasonally dry and scattered grassland, is extremely small. This population has an approximate altitude ranging from 200 to 300 m.a.s.l. This locality is characterized by an $\mathrm{AW}_{1}$ climate with two climatic subtypes according to the Koppen climate classification system modified by GARCÍA (1988). This type of climate is characterized by being hot and sub-humid, with an intermediate level of humidity, between $\mathrm{AW}_{0}$ and $\mathrm{AW}_{2}$, with rainfall in summer, and a mean annual temperature of the coldest month higher than $18{ }^{\circ} \mathrm{C}$ and the hottest month higher than $22^{\circ} \mathrm{C}$.

Sample collection was conducted in the $9.7 \mathrm{~km}^{2}$ area located on two hills in central Veracruz [OCTAVIO-AGUILAR \& al. 2017] from adult individuals sexually identified based on their reproductive structures. To conduct this study, 2-4 leaflets were collected from each of the 36 individuals (18 males and 18 females) in four $20 \mathrm{~m} \times 20 \mathrm{~m}$ plots. With the aid of a GPS (Garmin eTrex Legend, Olathe, Kansas, USA), all the individuals were georeferenced. Each leaf sample was individually labeled and transported in a cooler to the "Instituto de Biotecnología y Ecología Aplicada" (INBIOTECA), from "Universidad Veracruzana", for molecular studies.

Genomic DNA isolation. The genomic DNA from the collected individuals of $Z$. inermis was extracted using the STEWART \& VIA (1993) procedure, which depends on the use of CTAB (Cetyltrimethylammonium bromide, Sigma Aldrich). A fluorometer (Qubit 2.0, Invitrogen, USA) has been used to assess the purity of the DNA once it has been correctly obtained. Each sample's DNA stock solution was diluted to a concentration of $50 \mathrm{ngL}^{-1}$ for PCR amplification. The Bulk Segregant Analysis (BSA) method was used to establish six DNA bulk samples. The bulk DNA samples came from three individuals (one for each sex) [MICHELMORE $\&$ al. 1991]. This method was used to screen the individuals of known sex to rapidly detect markers linked to any genomic region that may be sex-linked. A potential sex-linked marker was one that was present in the sex bulks analyzed but not in the alternate sex bulk.

ISSR markers. Twenty-five ISSR primers were selected (UBC, University of British Columbia, Vancouver, Canada) (Table 1). 
Lourdes Georgina IGLESIAS-ANDREU \& Enrique FAVIÁN-VEGA

Table 1. List of ISSR primers, their sequences and annealing temperature

\begin{tabular}{lccc}
\hline No. & $\begin{array}{c}\text { ISSR } \\
\text { primer }\end{array}$ & $\begin{array}{c}\text { *Sequence of nucleotides } \\
\text { (5'-3') }\end{array}$ & Annealing temperature $\left({ }^{\circ} \mathbf{C}\right)$ \\
\hline 1 & UBC-809 & AGAGAGAGAGAGAGAGG & 52 \\
\hline 2 & UBC-818 & CACACACACACACACAG & 52 \\
\hline 3 & UBC-827 & ACACACACACACACACG & 52 \\
\hline 4 & UBC-829 & TGTGTGTGTGTGTGTGC & 52 \\
\hline 5 & UBC-848 & CACACACACACACACARG & 55 \\
\hline 6 & ISSR-01 & GTAGTAGATAGATA & 40 \\
\hline 7 & ISSR-02 & GTAGTAGATAGATARG & 45 \\
\hline 8 & ISSR-03 & GTAGTAGATAGATARY & 45 \\
\hline $\mathbf{9}$ & ISSR-04 & GACAGACAGACAGACA & 48 \\
\hline 10 & ISSR-05 & GACAGACAGACAGACARG & 55 \\
\hline 11 & ISSR-06 & GACAGACAGACAGACARY & 55 \\
\hline 12 & ISSR-07 & GACACGACACGACACGACAC & 55 \\
\hline 13 & ISSR-08 & ACTGACTGACTGACTG & 48 \\
\hline 14 & ISSR-09 & ACTGACTGACTGACTGRG & 55 \\
\hline 15 & ISSR-10 & ACTGACTGACTGACTGRY & 55 \\
\hline 16 & ISSR-11 & GATAGATAGATA & 35 \\
\hline 17 & ISSR-12 & GTAGTAGATAGATARG & 37 \\
\hline 18 & ISSR-13 & YRGATAGATAGATA & 37 \\
\hline 19 & ISSR-14 & GACAGACAGACAGACA & 40 \\
\hline 20 & ISSR-15 & GACAGACAGACARG & 45 \\
\hline 21 & ISSR-16 & YRGACAGACAGACA & 40 \\
\hline 22 & ISSR-17 & GACACGACAC & 40 \\
\hline $\mathbf{2 3}$ & ISSR-18 & ACTGACTGACTG & ACTGACTGACTG \\
\hline
\end{tabular}

${ }^{*} \mathrm{R}$, purine (A or $\left.\mathrm{G}\right)$, Y, pyrimidine (C or T). The primers selected are indicated in bold. UBC: University of British Columbia, Canada.

PCR reactions were performed in duplicate, using a reaction mix in a $25 \mu \mathrm{L}$ volume containing: $5 \mathrm{X}$ PCR buffer, $25 \mathrm{mM} \mathrm{MgCl} 2,5 \mathrm{mM}$ dNTPs, $25 \mathrm{pM}$ primers, $1.5 \mathrm{U}$ of Taq DNA polymerase, and $50 \mathrm{ng}$ of DNA. Amplifications were carried out in a thermal cycler (AXIGEN®, Foster City, California, USA) under the following thermal conditions: a 7-minute denaturation step at $94{ }^{\circ} \mathrm{C}, 35$ cycles of 30 seconds at $94{ }^{\circ} \mathrm{C}$ and 45 seconds at various alignment temperatures $\left(37-55^{\circ} \mathrm{C}\right)$, depending on the primer, and a 10 -minute final extension at $72{ }^{\circ} \mathrm{C}$. Positive and negative controls were included in all cases. Electrophoretic separations were performed at $100 \mathrm{~V}$ for $80 \mathrm{~min}$ on $2 \%(\mathrm{w} / \mathrm{v})$ agarose gels in $1 \mathrm{X}$ TAE buffer. A $100 \mathrm{bp}$ molecular weight marker (Bioline brand, Memphys, Tennessee, USA) was used to evaluate $5 \mu \mathrm{L}$ of each 
of the amplified products. Afterwards, the gels were stained with ethidium bromide $\left(10 \mathrm{mgmL}^{-1}\right)$ and photographed using a photo-documenter (UVP, Upland, California, USA).

Analysis of data. Based on the type of primer and their size in base pairs (bp), bands that exhibited appropriate resolution and reproducibility in the obtained band profiles were recorded in a primary data matrix (values of 1: presence and 0: absence of the band). The latter was determined using a 100-bp DNA molecular size marker (Bioline brand) as a reference. Using the Paleontological Statistics (PAST) software, the data matrix was analyzed using Principal Coordinate Analysis (PCA) to identify the grouping patterns among the genotypes evaluated according to their sex [HAMMER \& al. 2001].

\section{Results and discussions}

According to the results, only 6 of the 25 ISSR primers examined allowed for the detection of repeatable and reproducible band profiles. The ISSR protocol was correctly developed on this basis, enabling the detection of 56 and 59 bands, respectively, for the DNA bulk male and female samples evaluated. ISSR-18 was one of the primers in this analysis that had the best resolution and repeatability. In this study, the number of bands detected ranged from 7 to 14 in DNA bulk male samples and from 6 to 15 in DNA bulk female samples, with an average of nine ISSR bands in both sex expressions (Table 2).

Table 2. Sequence of ISSR primers and number of bands detected by sex

\begin{tabular}{lccc}
\hline \multirow{2}{*}{$\begin{array}{c}\text { ISSR } \\
\text { Primers }\end{array}$} & $\begin{array}{c}\text { *Sequence of nucleotides } \\
\left(\mathbf{5}^{\prime} \mathbf{- 3}\right)\end{array}$ & Male & Females \\
\cline { 3 - 4 } UBC-848 & CACACACACACACACARG & 7 & 7 \\
\hline ISSR-04 & GACAGACAGACAGACA & 14 & 13 \\
\hline ISSR-05 & GACAGACAGACAGACARG & 8 & 6 \\
\hline ISSR-06 & GACAGACAGACAGACARY & 10 & 15 \\
\hline ISSR-18 & ACTGACTGACTG & 9 & 10 \\
\hline ISSR-20 & YR ACTGACTGACTG & 7 & 8 \\
\hline Total & & $\mathbf{5 6}$ & $\mathbf{5 9}$ \\
\hline
\end{tabular}

${ }^{*} \mathrm{R}$, purine (A or G), Y, pyrimidine (C or T). Y: C/T; R: A/G. UBC: University of British Columbia, Canada.

The presence of an 867 bp band was detected with the ISSR-18 primer in four of the six DNA bulk samples of males and females examined; that is, it was present in $66 \%$ of the DNA samples of female individuals (Figure 1) evaluated. 


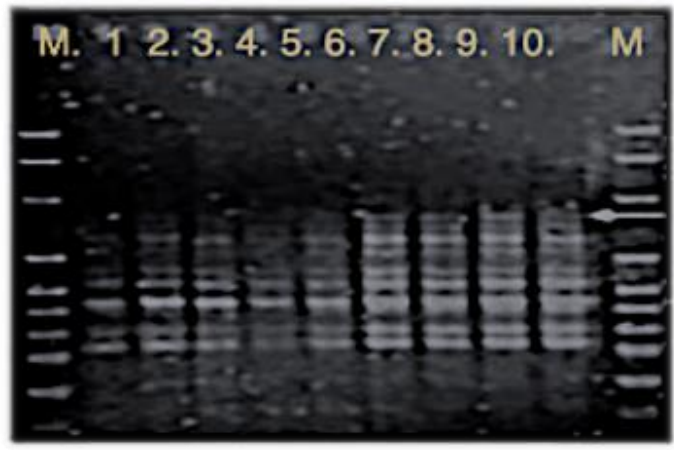

Figure 1. ISSR band profiles. The arrow indicates the $867 \mathrm{bp}$ band detected with the ISSR-18 primer in DNA bulk female samples. Lanes 3-8: DNA bulk male samples (1-5); lanes 6-10: DNA bulk female samples (from left to right); M: 100-bp ladder.

According to the results of principal coordinate analysis (PCA), the first two principal coordinates explained $72.17 \%$ of the total accumulated variance (Figure 2). DNA samples from sexually differentiated individuals were spatially distributed within the first two coordinates (Figure 2). Group I, located in the lower left part of the graph, explained $51.4 \%$ of the total variance. This group consisted of five bulk DNA samples, of which four corresponded to female bulk DNA samples. Group II, located at the top of the graph, explained $20.87 \%$ of the total accumulated variance (Figure 2). This group was composed of five DNA bulk samples, corresponding to one female DNA bulk sample and four male DNA bulk samples (Figure 2). It was not possible to observe in this study a clear grouping of individuals by sex, using Principal Coordinates Analysis (PCoA) due to the atypical spatial distribution presented by two of the bulk DNA samples evaluated (3M: bulk male DNA sample, and $6 \mathrm{H}$ : bulk female DNA sample) (Figure 2).

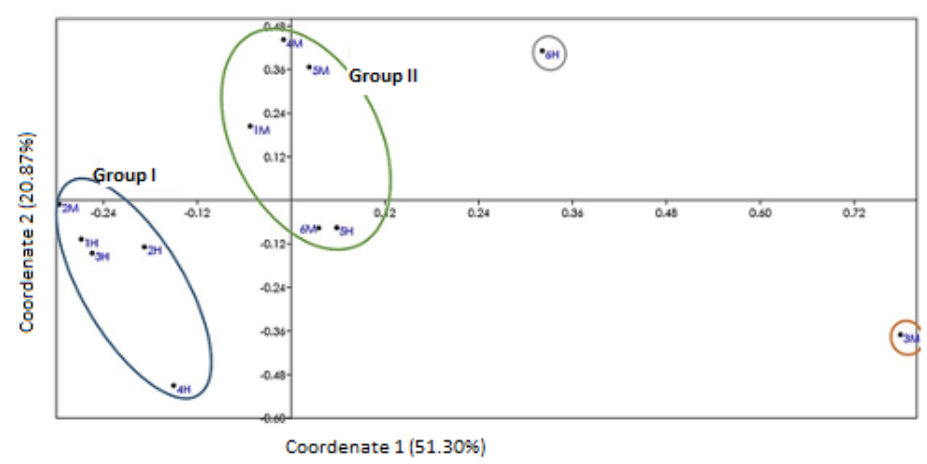

Figure 2. Principal Coordinates Analysis (PCoA) of DNA bulk samples of sexually differentiated individuals in Z. inermis. Group I (4 DNA bulk female samples), Group II (4 DNA bulk male samples). $\mathrm{H}=$ female, $\mathrm{M}=$ male.

Even though dioecy is a common trait among gymnosperms, accounting for roughly 65 percent of all currently identified species [WALAS \& al. 2018], the search for sex-cosegregating molecular markers in this group of plants has been limited [ROY \& al. 2012]. Sex- 
linked bands, as is widely known, occur rarely and not always in the same way. As is known, sex-linked bands usually occur very infrequently and not always consistently. As a result, very little is known regarding cycads, although they will presumably be the first dioecious seedbearing lineage and occupy a major evolutionary position among land plants.

In Zamia fischeri, two RAPD markers were reported to be linked with each sex, as well as a male gender-specific band which showed some homology with a microsatellite sequence from Araucaria angustifolia (Bertol.) Kuntze [ROY \& al. 2012], potentially useful for early male sex identification. Sex-specific RAPD markers have been identified in Cycas circinalis [GANGOPADHYAY \& al. 2007] and C. mexicana [IGLESIAS-ANDREU \& al. 2017].

It was interesting to find that the ISSR marker detected was associated with the female genotype even though, according to AINSWORTH (2000), most molecular markers are associated with the male sex. Bands are linked with the female sex in other cycad species, like Encephalitis natalensis. PRAKASH \& VAN STADEN (2006) found RAPD markers specific to the female method analysis, and a RAPD marker specific to the female gender in Cycas tanqingii, which was later converted to a "Sequence Characterized Amplified Regions" (SCAR marker) for use in male and female identification prior to flowering [JING \& al. 2007]. SCAR markers have the advantage of becoming more reliable and enabling the identification of a single locus [JIANG \& SINK, 1997].

The ISSR marker found to be associated with female sex in this study is only a starting point to contribute to sex identification in Z. inermis. However, it is necessary to validate its usefulness, for which future studies will be developed to detect a SCAR marker like those found in other gymnosperms [JING \& al. 2007; LIAO \& al. 2009; SÁNCHEZ-COELLO \& al. 2018].

\section{Conclusions}

The results demonstrated the ISSR marker linked with female sex found in Z. inermis is a suitable starting point to start looking for other genetic and epigenetic molecular markers to improve early sex identification in this significant genetic resource. We can't rule out the possibility that sex expression in this species is influenced by epigenetic factors (gene expression changes without changes in the nucleotide sequence), so it'd be advisable to evaluate the usefulness of markers such as Methylation-Sensitive Amplification Length Polymorphism (ms-AFLP) in elucidating the role of possible epigenetic factors in sex determination.

\section{Notes on contributors}

Lourdes Georgina IGLESIAS-ANDREU is a researcher at the Institute of Biotechnology and Applied Ecology of the "Universidad Veracruzana" Mexico, and a member of Mexico's National System of Researchers (SNI II) with expertise in plant genetics and biotechnology.

Enrique FAVIAN-VEGA - he has a PhD in Ecology and Biotechnology, and his work has focused on the conservation biology of Mexican cycads.

\section{Acknowledgements}

We would like to thank the "Consejo Nacional de Ciencia y Tecnología" (CONACyT) for the financial support provided for the development of Basic Science Project No. 152073. 


\section{References}

AINSWORTH C. 2000. Boys and girls come out to play: the molecular biology of dioecious plants. Annals of Botany. 86(2): 211-221. https://doi.org/10.1006/anbo.2000.1201

BALDO-ROMERO A. M., IGLESIAS-ANDREU L. G., VÁZQUEZ-TORRES S. M., SÁNCHEZ-VELÁZQUEZ L. R., LUNA-RODRÍGUEZ M. \& OCTAVIO-AGUILAR P. 2013. Marcadores morfométricos para la identificación del sexo en Zamia furfuracea L. f. (Zamiaceae). Revista Chapingo, Serie Ciencias Forestales y del Ambiente. 19(3): 425-434. https://doi.org/10.5154/r.rchscfa.2013.03.010

GANGOPADHYAY G., ROY S. K., GHOSE K., PODDAR R., BANDYOPADHYAY T., BASU D. \& MUKHERJEE K. K. 2007. Sex detection of Carica papaya and Cycas circinalis in pre-flowering stage by ISSR and RAPD. Current Science. 92(4): 524-526.

GARCÍA E. 1988. Modificaciones al sistema de clasificación climática de Kóppen, para adaptarlo a las condiciones de la República Mexicana. 4a edición corregida, aumentada con un mapa de climas según el sistema y un diagrama de flujo para clasificar el clima, y actualizada a 1980 con promedios de 2000 estaciones. Offset Larios, México, D. F., 220 p.

HAMMER O., HARPER A. T. \& RYAN P. D. 2001. Past: Paleontological Statistics Software Package for Education and Data Analysis. Palaeontología Electrónica. 4(1): art. 4, 9 p.

IGLESIAS-ANDREU L. G., LUNA-RODRIGUEZ M., DURÁN V. M., RIVERA-FERNÁNDEZ A. \& SÁNCHEZCOELLO N. 2010. Marcadores RAPDs asociados a la expresión del sexo en Ceratozamia mexicana Brongniart (Zamiaceae). Revista Chapingo, Serie Ciencias Forestales y del Ambiente. 16: 139-145. https://doi.org/10.5154/r.rchscfa.2010.04.016

IGLESIAS-ANDREU L. G., OCTAVIO-AGUILAR P., VOVIDES A. P., MEEROW A. W., DE CÁCERES-GONZÁLEZ F. N. \& GALVÁN-HERNÁNDEZ D. M. 2017. Extinction Risk of Zamia inermis (Zamiaceae): a genetic approach for the conservation of its single natural population. International Journal of Plant Sciences. 178(9): 715-723. https://doi.org/10.1086/694080

IUCN. 2011. Red List of Threatened Species. http://www.iucnredlist.org (Mar. 6, 2015).

JIANG C. \& SINK K. C. 1997. RAPD and SCAR markers linked to the sex expression locus $M$ in asparagus. Euphytica. 94: 329-333. https://doi.org/10.1023/A:1002958007407

JING J. Z., JIN H., LI D. L., CHEN X. K. \& ZHANG Y. 2007. RAPD and SCAR molecular markers linked to the sexuality of cycads (Cycas tanqingii D. Y. Wang). Sheng Wu Gong Cheng Xue Ba. 23(6): 1097-1101.

LIAO L., LIU J., DAI Y., LI Q., XIE M., CHEN Q., YIN H., QIU G. \& LIU X. 2009. Development and application of SCAR markers for sex identification in the dioecious species Ginkgo biloba L. Euphytica. 169: 49-55. https://doi.org/10.1007/s10681-009-9913-8

MARTÍNEZ-DOMÍNGUEZ L., NICOLALDE-MOREJÓN F., VERGARA-SILVA F. \& STEVENSON D. W. 2018. Las cícadas y los códigos de barras genéticos. Ciencia y Desarrollo. 44(297): 64-69.

MICHELMORE R. W., PARAN I. \& KESSELI R. V. 1991. Identification of markers linked to disease resistance genes by bulked segregant analysis: A rapid method to detect markers in specific genome regions by using segregating populations. Proceedings of the National Academy of Sciences of the United States of America. 88(21): 9828-9832. https://doi.org/10.1073/pnas.88.21.9828

OCTAVIO-AGUILAR P., IGLESIAS-ANDREU L. G., VOVIDES A. P. \& RIVERA-FERNÁNDEZ A. 2017. Zamia inermis, la cícada más amenazada de México. Cuadernos de Biodiversidad. 52: 1-5. https://doi.org/10.14198/cdbio.2017.52.01

PRAKASH S. \& VAN STADEN J. 2006. Sex identification in Encephalartos natalensis (Dyer and Verdoorn) using RAPD markers. Euphytica. 152(2): 197-200. https://doi.org/10.1007/s10681-006-9198-0

ROY S. K., GANGOPADHYAY G. \& MUKHERJEE K. K. 2012. Determination of sex in Zamia fischeri Miq., an endangered gymnosperm. International Journal of Biodiversity and Conservation. 4(7): 287-293. https://doi.org/10.5897/IJBC11.269

SÁNCHEZ-COELLO N. G., IGLESIAS-ANDREU L. G., LUNA-RODRÍGUEZ M., OCTAVIO-AGUILAR P., VÁZQUEZ-TORRES M., RIVERA-FERNÁNDEZ A. \& ADAME-GARCÍA J. 2018. The needly gene is associated with sexual expression in Ceratozamia mexicana Brongn. (Zamiaceae). In: LI N., STEVENSON D. W. \& GRIFFITH M. P. (eds.). Cycad Biology and Conservation: The $9^{\text {th }}$ International Conference on Cycad Biology. New York Botanical Garden Press, New York: 193-204.

SÁNCHEZ-TINOCO M. Y., VÁZQUEZ-TORRES M. \& ALEJANDRE-ROSAS J. A. 1990. Determinación del dimorfismo sexual en una población de Ceratozamia mexicana Brongn. (Zamiaceae). Delpinoa. 29-30: 7-35.

SÁNCHEZ-TINOCO M. Y., VÁSQUEZ-TORRES M. \& CRUZ-KURI L. 1993. Determinación del dimorfismo sexual en Zamia inermis Vovides, Rees \& Vázquez Torres, Zamiaceae (Cycadales), basado en características morfológicas vegetativas. La Ciencia y el Hombre. 15: 113-127. 


\section{IDENTIFICATION OF SEX IN ZAMIA INERMIS USING ISSR MARKERS}

SEMARNAT. 2010. Norma Oficial Mexicana NOM-059-SEMARNAT-2010, Protección Ambiental-Especies Nativas de México de Flora y Fauna Silvestres-Categorías de Riesgo y Especificaciones Para su Inclusión, Exclusión o Cambio-Lista de Especies en Riesgo. Diario Oficial de la Federación. D. F., México. http://dof.gob.mx/normasOficiales/4254/semarnat/semarnat.htm (May 14, 2012).

STEWART C. N. \& VIA L. E. 1993. A rapid CTAB DNA isolation technique useful for RAPD fingerprinting and other PCR applications. BioTechniques. 14(5): 748-750.

VOS P., HOGERS R., BLEEKER M., REINJANS M., VAN DE LEE T., HORNES M., FRIJTERS A., POT J., PELEMAN J., KUIPER M. \& ZABEAU M. 1995. AFLP: a new technique for DNA fingerprinting. Nucleic Acids Research. 23(21): 4407-4414. https://doi.org/10.1093/nar/23.21.4407

VOVIDES A. P. 1983. Flora de Veracruz, Zamiaceae. Fascículo 26. Instituto Nacional de Investigaciones Sobre Recursos Bióticos, Xalapa, México.

WALAS L., MANDRYK W., THOMAS P. A., TYRAŁA-WIERUCKA Z. \& ISZKUŁO G. 2018. Sexual systems in gymnosperms: a review. Basic and Applied Ecology. 31: 1-9. https://doi.org/10.1016/j.baae.2018.05.009

WILLIAMS J. G. K., KUBELIK A. R., LIVAK K. J., RAFALSKI J. A. \& TINGEY S. V. 1990. DNA polymorphism amplified by arbitrary primers are useful as genetic markers. Nucleic Acids Research. 18(22): 6531-6535. https://doi.org/10.1093/nar/18.22.6531

ZIETKIEWICZ E., RAFALSKI A. \& LABUDA D. 1994. Genome fingerprinting by simple sequence repeat (SSR)anchored polymerase chain reaction amplification. Genomics. 20(2): 176-183.

https://doi.org/10.1006/geno.1994.1151

How to cite this article:

IGLESIAS-ANDREU L. G. \& FAVIAN-VEGA E. 2021. Identification of sex in Zamia inermis using ISSR markers. J. Plant Develop. 28: 33-40. https://doi.org/10.47743/jpd.2021.28.1.897 